\title{
Kolme oppimismuotoa sosiaalisessa kontekstissa
}

Jarvis, Peter 1989. Kolme oppimismuotoa sosiaalisessa kontekstissa. Aikuiskasvatus 9, 1. 1218.

- Artikkelissa käsitellään sosiaalisessa kontekstissa tapahtuvan oppimisen kolmea eri muotoa. Artikkeli perustuu vuonna 1985 ja 1986 tehtyyn aikuisten oppimistapoja kartoittavaan tutkimukseen, jossa oli mukana noin 200 aikuisopintoihin osallistunutta henkilöä sekä Englannista että Yhdysvalloista. Tutkimuksessa lähdettiin Kolbin oppimissyklimallista, mutta sitä pyrittiin kehittämään edelleen. Oppimisen todetaan perustuvan aina kokemukseen. Tämän perusteella erotettiin kolme perusteiltaan erilaista oppimistyyliä, jotka ovat ei-oppiminen, eireflektiivinen oppiminen sekä reflektiivinen oppiminen. Artikkelissa analysoidaan tarkemmin näille oppimistyyleille ominaisia reagointimalleja ja niiden yhteyksiä sosiaaliseen kontekstiin.

Tässä artikkelissa käsitellään oppimisen eri muotoja sosiaalisessa kontekstissa. Oppimismuodot hahmottuivat tutkimushankkeessa, jossa tutkittiin aikuisten oppimistapoja. Siinä tehdyissä analyyseissä pyrittiin oppimismallit sijoittamaan laajempaan sosiaaliseen kontekstiin. Kyseessä on kokeileva, oppimisen sosiologiaan suuntautunut tutkimushanke. Koska tässä ei ole mahdollista paneutua oppimisen tarkempaan määrittelyyn, niin esitän vain seuraavan määritelmän: oppiminen on kokemuksen muuntumista tiedoiksi, taidoiksi ja asenteiksi. Kuvailen ensin lyhyesti itse tutkimusprojektia ja sen tuloksia, sitten käsittelen oppimisen kolmea päämuotoa, ja lopussa on lyhyt yhteenveto.

\section{Tutkimusprojekti}

Joukko aikuisia osallistui vuosina 1985 ja 1986 noin viidentoista kuukauden ajan tutkimukseen, jonka tarkoituksena oli saada lisätie- toja aikuisten oppimistavoista. Kaikkia osallistujia pyydettiin ensin kirjoittamaan joku heidän elämässään sattunut oppimistapahtuma. Heitä pyydettiin kertomaan, mikä laukaisi tapahtuman, kuinka se eteni ja lopuksi, milloin ja miksi he katsoivat sen päättyneen. Tämän tehtävän jälkeen heidät ryhmiteltiin pareiksi, jotta he voisivat keskustella oppimiskokemuksistaan keskenään, ja heitä kehotettiin tarkastelemaan kokemustensa yhtäläisyyksiä ja eroja. Sen jälkeen pantiin kaksi paria yhteen keskustelemaan neljästä eri oppimiskokemuksestaan. Tällä kertaa heitä pyydettiin piirtämään yhteisistä oppimiskokemuksistaan yksinkertainen malli ja jotkut ryhmistä kykenivätkin laatimaan melko pitkälle eriteltyjä oppimismalleja.

Ensimmäisellä kerralla, kun tämä harjoitus toteutettiin, ryhmiä pyydettiin kertomaan harjoituksen aikana syntyneistä ajatuksistaan käydyn yleiskeskustelun yhteydessä. Sitten heille annettiin kopio Kolbin (1984) oppimissyklistä ja heitä kehotettiin soveltamaan sitä omiin kokemuksiinsa. 


\section{KOLBIN OPPIMISSYKLI}

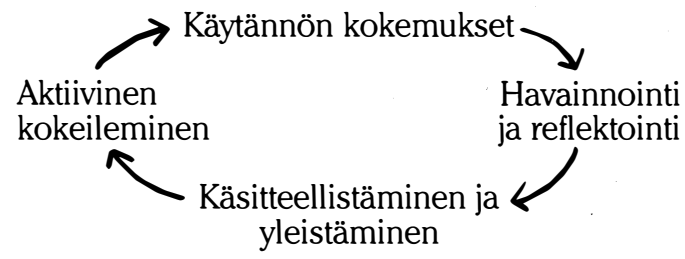

Osanottajille kerrottiin, ettei sykli välttämättä ole täysin oikea ja että he voivat soveltaa sitä vapaasti haluamallaan tavalla, niin että se vastaisi heidän kokemuksiaan. Ensimmäisen ryhmäasetelman antaman palautteen perusteella laadittiin sitten mutkikkaampi oppimismalli muokkaamalla yllä esitettyä oppimissykliä niin, että se vastasi jokaisen neljästä ihmisestä koostuneen ryhmän tuloksia. Aina kun tämä tehtävä sen jälkeen toistettiin, tarkoituksena oli joka kerta ottaa käyttöön se Kolbin syklin sovellutus, joka oli hahmottunut aikaisemmasta vaiheesta saatujen tulosten perusteella.

Tämä sama harjoitus käytiin läpi yhdeksässä eri tilaisuudessa sekä Englannissa että Yhdysvalloissa ja siihen osallistui sekä aikuisopettajia että koulunopettajia, yliopistonopettajia ja aikuisia korkeakouluopiskelijoita, jotka opettivat kokopäivätoimisesti aikuisia, nuorehkoja ja vanhahkoja henkilöitä sekä miehiä että naisia. Kaiken kaikkiaan kokeeseen osallistui pari sataa ihmistä, jotka edustivat lähinnä keskiluokkaa. Kokeeseen osallistujia ei pyritty rajaamaan tiukasti. Tutkimuksen tuloksena syntyi monimutkainen oppimismalli, jota testattiin yhdeksän kuukauden aikana erilaisissa sekä Englannissa että Yhdysvalloissa toteutetuissa seminaareissa, joihin osallistui 200-300 henkilöä. Tämän artikkelin tarkoitus ei oikeastaan ole tarkastella mallia sellaisenaan, vaan eritellä niitä erilaisia oppimisreaktioita, joita tutkimuksessa saatiin selville.

Artikkelin alussa esitetystä oppimisen määritelmästä huomataan, että sen mukaan kaiken oppimisen voidaan väittää alkavan kokemuksesta, joten oppimista on järkevää tarkastella vastauksena kokemukseen. Periaatteessa on olemassa yhdeksän eri tyyppistä tapaa suhtautua kokemukseen ja että ne voidaan luokitella kolmeen perusteiltaan erilaiseen oppimistyyppiin: ei-oppiminen (non-learning), ei-reflektiivinen oppiminen (non-reflective learning) ja reflektiivinen oppiminen (reflective learning). Kukin näistä kolmesta tyypistä käsittää kolme alatyyppiä ja reflektiiviseen oppimiskerrostumaan sisältyy kaksi muotoa kustakin kolmesta tyypistä.

\section{Ei-oppiminen sosiaalisessa kontekstissa}

On selvä, että ihmiset eivät aina opi kokemuksistaan ja niinpä ensimmäinen reaktioryhmä käsittää reaktiot, joiissa oppimista ei tapahdu. Näitä ovat perinteiseen pitäytyminen (presumption). välinpitämättömyys (non-consideration) ja torjunta (rejection).

\section{Perinteiseen pitäytyminen}

Perinteiseen ajattelumalliin pitäytyminen on melko tyypillinen tapa reagoida arkiseen kokemukseen. Schutz ja Luckmann $(1974,7) \mathrm{ku}-$ vailevat sitä näin:

Luotan siihen että maailma jatkuu samaa rataa sellaisena kuin minä olen sen tähän asti tuntenut ja että sen takia kanssaihmisiltä saamani ja omán kokemukseni perusteella muokkaamani tietovarasto pysyy edelleenkin pohjimmiltaan pätevänä... Tästä olettamuksesta seuraa toinen, perustavanlaatuinen olettamus: minä voin toistaa menneet menestykselliset tekoni. Niin kauan kuin maailman rakennetta voidaan pitää pysyvänä, niin kauan kuin aiemmat kokemukseni ovat päteviä, minun kykyni toimia tässä maailmassa pysyvät periaatteessa tallella.

Vaikka saattaa tuntua melko ajattelemattomalta ja mekaaniselta, niin esitän, että tällainen suhtautumistapa on kaiken yhteisöelämän perusta. Ihmisistä tuntuisi aika sietämättömältä, jos heidän täytyisi harkita joka kerta etukäteen jokaista sanaansa ja tekoansa jokaisessa sosiaalisessa tilanteessa. Niinpä suuri osa elämää eletään aiemmin opittujen kokemusten pohjalta ja perinteiseen ajatteluun pitäytyminen on tyypillinen suhtautumistapa.

\section{Välinpitämättömyys}

Ihmiset eivät monista eri syistä reagoi mahdolliseen oppimiskokemukseen; ehkä heillä on liian kiire, jotta he ehtisivät ajatella sitä tai he saattavat pelätä, mitä siitä koituu jne. Niinpä välinpitämättömyys saattaa olla toinen melko usein jokapäiväisessä elämässä esiintyvä tapa suhtautua mahdollisiin oppimiskokemuksiin.

\section{Torjunta}

Joillakin ihmisillä on kokemus, he ajattelevat sitä, mutta torjuvat oppimismahdollisuuden, joka olisi saattanut seurata kokemuksesta. Ajatelkaamme esimerkiksi vanhahkoa ihmistä, joka kokee nykyajan monimutkaisuuden ja huudahtaa: Minä en tiedä, mihin tässä maailmassa vielä tätä menoa joudutaankaan! Tässä olisi mahdollinen oppimiskokemus, kokemus mutkikkaasta nykyajan maailmasta, mutta 
sen sijaan että tutkailisi ja yrittäisi ymmärtää sitä henkilö torjuu mahdollisuuden. Vaikka suhtautumistapaa on kuvattu tässä vanhan ihmisen näkökulmasta, niin sitä olisi voitu havainnollistaa myös sellaisen nuoremman kiihkoilijan avulla, joka katselee maailmaa ja sanoo, ettei hän anna minkään siinä muuttaa mielipidettään tai asennettaan.

Sosiologisesti merkittävä seikka missä tahan'sa suhtautumisessa kokemukseen on se, ettei kukaan ole täysin yksilö, jokainen elää yhteisössä. Mitä siitä sitten seuraa, kun oppimista ei tapahdu? Se etteivät ihmisten kokemukset vaikuta yhteiskuntaan ja sen rakenteisiin. Ettei mitään muutostä todennäköisesti tapahdu, koska ihmisten tiedoissa, taidoissa ja asenteissa ei ole tapahtunut mitään muutosta. Ihmiset ovat hỳväksyneet tai torjuneet sen mitä heille on esitetty, mutta he eivät ole oppineet siitä mitään, joten mitään sellaista ei voi tapahtua, mikä muuttaisi yhteiskuntaa. Tässä voidaan vetää ainakin kaksi johtopäätöstä; toinen koskee ihmistä, toinen yhteiskuntaa.

Ihminen, joka kulkee läpi elämänsä tarkastellen maailmaa usein omahyväisesti tai ottaen siihen jopa välinpitämättömän asenteen, tuntee olevansa yhiteiskunnan rakenteiden sisällä täysin vapaa, koska nämä rakenteet ilmenevät juuri hänen odottamallaan tavalla. Ihminen voi kokea henkilökohtaisen vapauden tunnetta yksinkertaisesti siksi, että yhteiskunta ei näytä pakottavan yksilöä tekemään mitään sellaista, mitä hän ei halua. Kun yksilö taas torjuu mahdollisen oppimisen, yhteiskunnalliset paineet tuntuvat usein tukahduttavilta. Silti henkilöllä voi olla yksilöllisen vapauden tunne, tunne siitä, ettei hänen tarvitse itse vastata noihin yhteiskunnallisiin paineisiin. Tämä on negatiivista vapautta, joka auttaa ihmistä pysyttelemän loitolla ja torjumaan ne sosiaaliset voimat, joita häneen väkisin kohdistetaan. Niinpä ihminen voi yhä tuntea olevansa vapaa toimimaan niin kuin haluaa, vaikka paineet näyttävätkin tukahduttavilta.

Vastakohtana tälle yhteiskunnan voidaan nähdä pysyvän muuttumattomana: ne joilla on valtaa, käyttävät sitä edelleenkin; ne jotka esittävät tiedotusvälineissä tulkintoja maailmassa, esittävät niitä edelleenkin; ne jotka maalailevat yhteiskunnan 'pahuuksia', lausuvat tuomioitaan maailmasta edelleenkin. Heidän haasteisiinsa ei useinkaan vastata. Ehkä se ettei onnistuta vastaamaan niiden haasteisiin, jotka käyttävät valtaa tai muokkaavat tiedotusvälineissä tulkintoja maailmasta jne., on vain sitä ettei oppimista tapahdu tai ehkä se on apatiaa? Se on myös tulosta siitä, ettei oppimista tapahdu sosiaalisessa kanssakäymisessä. Mutta entä ne, jotka käyttävät valtaa todella? He voivat käyttää valtaansa peitellysti, eikä heidän tarvitse koskaan saada ihmisiä hyväksymään heitä tai heidän käsityksiään maailmasta. Juuri tätä Gramsci nimitti hegemoniaksi ja Williams (1976, 205) kuvaili sen olevan:

...käytännön ja odotusten muodostama kokonaisuus, se mihin me suuntaamme energiamme, meidän tavanomainen käsityksemme ihmisen ja hänen maailmansa luonteesta. Se on merkitysten ja arvojen järjestelmä, ja kun ne koetaan käytäntöinä, ne vahvistavat toinen toisiaan. Täten se muodostaa useimmille yhteiskunnan jäsenille käsityksen todellisuudesta, käsityksen ehdottomasta, koska se koetaan todellisuudeksi, jonka yli useimpien yhteiskunnan jäsenten on hyvin vaikea astua useimmilla elämänsä alueilla.

Näin ei-oppiminen vahvistaa vallassaolijoiden ja niiden asemia, jotka muokkaavat ja tulkitsevat todellisuutta ihmisille. Merkittävää kuitenkin on, että ilman ei-oppimista ei mikään yhteiskunta tai organisaatio voi olla pysyvä. Siksi se on olennaisen tärkeä yhteiskunnan jatkuvuudelle, oli kysymys sitten minkälaisesta yhteiskunnasta hyvänsä.

\section{Ei-reflektiivinen oppiminen sosiaalisessa kontekstissa}

Nämä oppimismuodot ovat niitä, joita on kaikkien useimmin pidetty yhteiskunnassa oppimisena. Mukavuussyistä ne kolme muotoa, jotka on eritelty tässä tutkimushankkeessa ovat seuraavat: tiedostamaton oppiminen, taitojen oppiminen ja muistaminen. Tärkein tekijä, mistä syystä ne voidaan sijoittaa samaan kerrostumaan, on se, ettei niihin sisälly reflektiota.

\section{Tiedostamaton oppiminen}

Tiedostamaton oppiminen (pre-conscious) on oppimislaji, jota on tutkittu hyvin vähän. Sitä tapahtuu jokapäiväisessä elämässä kokemusten kautta ilman, että sitä oikeastaan ajatellaan tai tullaan siitä edes erityisen tietoiseksi. Sitä voi sattua näkökyvyn laitamilla, tietoisuuden reunamilla jne. Ruth Beard (1976, 93-95) kutsuu tätä satunnaiseksi oppimiseksi ja esittää, että ihmiset kehittävät näiden kokemusten johdosta sellaisia ilmiöitä kuin havaintokaavat. Tästä lähestymistavasta kiinnostuneisiin oppineisiin kuuluvat Mennings (1936), joka tutki satunnaista oppimista aikuisoppilaitoksessa, ja Reischmann (1986), joka AAACE:ssä pitämässään esitelmässä puhui oppimisesta en passant (ohimennen tapahtuvana). Tämän tutkimusprojektin tarkoitus ei ollut analysoida tätä oppimistyyppiä, vaikka joukko vastaajia mainitsikin tämän mahdollisuuden tutkimuksen aikana. Se muistuttaa lähestymistavaltaan kahta seuraavaa oppimisen muotoa. 


\section{Taitojen oppiminen}

Taitojen oppiminen (skills learning) rajoitetaan perinteisesti sellaisiin oppimismuotoihin kuin koulutus käden taitoja vaativaan ammattiin tai korkean fyysisen kunnon saavuttamiseen harjoituksen avulla. Mutta valmentauduttaessa käden taitoja vaativaan ammattiin osa oppimisesta on taatusti reflektoivaa, joten tämä oppimismuoto täytyy rajoittaa sellaisten yksinkertaisten, lyhyiden työskentelytapojen oppimiseen, joita saatetaan opettaa liukuhihnalla työskentelevälle. Nämä taidot hankitaan usein matkimalla ja roolia jäljittelemällä.

\section{Muistiin painaminen}

Muistaminen (memorization) on ehkä oppimisen tunnetuin muoto. Lapset oppivat näin matemaattiset taulukot, kielen sanaston jne. Palatessaan korkeamman opetuksen pariin aikuisista joskus tuntuu, että heiltä odotetaan juuri tämänlaatuista oppimista ja niin he yrittävät painaa mieleensä, mitä se ja se oppinut on kirjoittanut voidakseen toistaa tämän tentissä. Tämän vuoksi auktoriteetin puhe ja jokainen viisas sana täytyy opetella, painaa muistiin.

Näiden lähestymistapojen merkitys oppimiselle laajemmassa sosiaalisessa kontekstissa käy hyvin selväksi. Niin kauan kuin oppimiseen suhtaudutaan näin, oppiminen ei ole muuta kuin jäljentämisprosessi. Yhteiskuntaa ja sen rakenteita ei aseteta kyseenalaisiksi ja siksi ne pysyvät muuttumattomina. Ihmiset oppivat ja sopeutuvat tämän vuoksi helposti suurempaan organisaatioon tai laajempaan yhteisöön, he oppivat hyväksymään paikkansa niinkuin se on. Asiaa voidaan jälleen tarkastella niin yksilön kuin laajemman yhteisön kannalta.

Yksilöt, jotka oppivat tällä tavalla, oppivat todellakin sopeutumaan organisaatioon tai yhteiskuntaan sellaisenaan. He kokevat tietyn asteista vapautta sikäli, kun yhteiskunta ei vaikuta kohtuuttoman tukahduttavalta, ja niin kauan kun he hyväksyvät sen, mikä heidän odotetaan oppivan, ei näytä syntyvän mitään ongelmia. Ehkä vielä tärkeämpää on se, että yhteiskunnan rakenteet vaikuttavat suhteellisen hyväksyttäviltä eivätkä aiheuta oppijille mitään suurempia ongelmia.

Yhteiskunnan on uusinnettava itseään tai ainakin niiden, jotka käyttävät valtaa yhteiskunnassa täytyy uusintaa yhteiskunnalliset suhteet samanlaisina kuin he kokevat. Vain näin he voivat olla varmoja siitä, että ihmiset oppivat ne ja uusintavat niitä. Jos oppiminen ymmärretään uusintamisena, niin tämä taatusti edistää prosessia! Mitä enemmän koulutuksen ja tutkintojärjestelmän katsotaan tukevan uusintamisprosessia, sitä enemmän voidaan valtaa yhä käyttää peitellysti. Bourdieu ja Passeron (1977) väittävät, että opetus joka ikuistaa tämän prosessin on itse asiassa vertauskuvallista väkivaltaa, koska se pakottaa oppijat ehkä tietämättömyyttään omaksumaan tulkintoja, jotka saattavat olla heidän tilannettaan ajatellen vääriä. Tämä saattaa tietysti pitää paikkansa myös tiedotusvälineiden tulkintojen kohdalla, vaikka aina onkin olemassa mahdollisuus, ettei niitä hyväksytä. Opiskelijoille annetun tiedon hylkääminen on kuitenkin ongelmallisempaa oppilaitoksessa, varsinkin jos tieto kuuluu osana tutkintojärjestelmään! Bowles ja Gintis (1976, 103) kirjoittavat:

Me väitämme, että meritokratian julkisivun alla piilee itse asiassa koulutusjärjestelmä, joka on kytketty sellaiseen taloudellisten suhteiden uusintamiseen, jota voidaan vain osittain selittää teknisten ja suorituskykyvaatimusten avulla. Niinpä esitämme ensiksi, että kilpailevaan arvoasteikkoon ja objektiivisiin koepistemääriin perustuva koulutusura liittyy vain vähäiseltä osin yhteiskunnalliseen tehokkuuteen. Näin me törmäämme pää edellä teknologismeritokraattiseen ideologiaan näyttämällä, että koulutuksen pituuden ja taloudellisen menestyksen välistä yhteyttä ei voida selittää opiskelijoiden kognitiivisten saavutusten avulla. Niinpä koulutuksellisen meritokratian mittapuu - koepistemäärät - vaikuttavat hämmästyttävän vähän yksilön taloudelliseen menestykseen. Koulutuksellinen meritokratia on suuresti symbolista.

Mutta symbolismi on välttämätöntä, jotta yhteiskunnallisten ja taloudellisten suhteiden uusiutuminen voi tapahtua ilman, että tarvitsee harjoittaa avointa valtaa. Koulutusmahdollisuus on vain osa avoimen yhteiskunnan myyttiä. Oppiminen on osa tätä samaa prosessia: ei-reflektiivistä oppimista voidaan kannustaa ilman että organisaation tai yhteiskunnan valtarakenteita asetetaan mitenkään kyseen- ja kiistanalaisiksi.

\section{Reflektiivinen oppiminen sosiaalisessa kontekstissa}

Toistaiseksi on osoitettu, että oppimisella on taipumus olla uusiutuvaa yksinkertaisesti siksi, että se määritellään usein näin yhteiskunnalliseksi. Esitin, ettei ei-reflektiivisessä oppimisessa kyetä muuhun kuin yhteiskunnallisten rakenteiden uusintamiseen sellaisenaan, mutta tämä ei pidä paikkaansa reflektiivisen oppimisen kohdalla. Nämä oppimismuodot sisältävät reflektio-prosessin ja sellaiset ajattelijat kuin Freire (1972a, 1972b inter alia), Mezirow 
(1977, 1981), Argyris (1982 inter alia), Schon (1983 inter alia), Kolb (1984) ja Boud et al (1985) ovat kaikki tutkineet reflektioprosessia. Freiren työn tuloksena voidaan olettaa, että kaiken reflektiivisen oppimisen täytyy olla vallankumouksellista, mutta näin ei pidä ajatella. Reflektiivinen oppiminen ei ole automaattisesti uudistavaa. Mutta ennen kuin käsittelemme tätä, on tarpeen tutkia kolmea reflektiivisen oppimisen muotoa, jotka havaittiin tässä tutkimuksessa. Ne ovat kontemplaatio (tarkkaileva mietiskely), reflektiivinen taitojen oppiminen (reflective skills leaming) ja kokeileva oppiminen (experimental learning).

\section{Kontemplaatio}

Kontemplaatio (contemplation) on oppimismuoto, jota behavioristiset ilmiön määritelmät eivät lainkaan ota lukuun. Kuitenkin sitä voidaan monella tapaa pitää hyvin älyllisenä lähestymistapana oppimiseen, koska se sisältää puhtaan ajattelun. Kyseessä on prosessi, jossa ajatellaan kokemusta ja päädytään siitä johtopäätökseen suhteuttamatta sitä laajempaan yhteiskunnalliseen todellisuuteen. Tämä uskonnollissävytteinen termi valittiin tarkoituksellisesti, koska siihen voidaan sisällytää niin meditaatio kuin filosofinen ajatteluprosessi sekä puhtaasti matemaattiset toiminnot.

\section{Reflektiivinen taitojen oppiminen}

Reflektiivistä taitojen oppimista kutsutaan kirjassa Adult Learning in the Social Context, reflektiiviseksi harjoitteluksi. Tämä on yksi niistä oppimismuodoista, joihin Schön keskittyy osoittaessaan, että ammattilaiset käyttävät ammattia harjoittaessaan talonpoikaisjärkeä. Reagoidessaan tilanteen ainutlaatuisuuteen he tuottavat usein prosessin aikana uusia taitoja. Aiemminhan osoitettiin, ettei ole monia sellaisia taitoja, jotka opitaan täysin ajattelematta, joten tätä voidaan pitää syvällisempänä lähestymistapana oppia käytännöllisiä aineita. Kysymys ei ole vain jonkin taidon oppimisesta, vaan käytäntöä lujittavan tiedon oppimisesta ja siitä miksi taito pitäisi suorittaa juuri tietyllä tavalla.

\section{Kokeileva oppiminen}

Kokeileva oppiminen on oppimismuoto, jossa teoriaa kokeillaan käytännössä. Kokeilun lopputuloksena on tiedon muoto, joka suhteutuu täysin yhteiskunnalliseen todellisuuteen. Tämä lähestymistapa on hyvin läheistä sukua Kellyn (1963) käsitykseen ihmisistä tiedemiehinä, jotka pyrkivät aina kokeilemaan ympäristöään:

Edellä osoitettiin, ettei näịden kolmen oppi- mismuodon tarvitse aina olla uudistavia tai muutokseen suuntautuvia. Palauttakaamme mieleen, että Argyrisilla 1982, 159-160 oli kaksi oppimistyyppiä, joita käsitellessään hän tähdensi seuraavaa:

Ensiksi on väärinkäsitys, että Malli II:n tavoite implikoi,että Malliı on jotenkin huono tai tehoton ja että se pitäisi hylätä. Malli I on päinvastoin sopivin teoria käytännön rutiineihin, ohjelmoituihin toimintoihin tai hätätilanteisiin (kuten henkiinjääneiden pelastaminen) jossa tarvitaan ripeää, yhdensuuntaista toimintaa. Meidän täytyy muistaa, että kaikki organisaatiot pyrkivät hajottamaan kaksoissidos-ongelmat (double loop problems) yksisidoksisiin. Suurin osa jokapäiväisestä oppimisesta jossakin organisaatiossa liittyy yksisidoksiseen oppimiseen. Kaksoissidos-oppiminen on kuitenkin ratkaisevaa, koska se antaa meille mahdollisuuden tutkia ja korjata sitä tapaa, jolla käsittelemme mitä tahansa ongelmaa ja siihen liittyviä olettamuksiamme.

Argyrisille uudistavammat oppimismuodot ovat siis olennaisia, mutta muut lähestymistavat ovat aivan yhtä tärkeitä. Siinä kun hän käytti termejä yksi- ja kaksoissidosongelma, niin tässä esitetään käytettäväksi ilmaisuja konformistinen ja innovatiivis-reflektiivinen oppiminen. On tarpeen käsitellä näitä molempia termejä hiukan tarkemmin. Botkin et al (1976) käyttävät termejä säilyttäminen (maintenance) ja innovatiivinen oppiminen (innovative learning) ja nämä käsitteet heijastavat tässä esitettyjä ideoita. Muistettakoon, että Freire (1972a, 1972b inter alia) myönsi, että hänen kasvatusmuodoissaan oli kaksi erilaista suhtautumistyyppiä: toista, jossa oppiminen oli ei-reflektiivistä, hän nimitti säilytettäväksi kasvatukseksi, ja toista, jossa oppimisessa pyritään innovaatioiden aikaansaamiseen, hän nimitti 'ongelmanasettelukasvatukseksi'. Freire ei kuitenkaan itse asiassa laatinut täydellistä oppimistypologiaa ja hän on jättänyt pois joitakin välimuotoja, joten hänen 'ongelmanasettelukasvatuksensa' liittyy vain osittain innovatiivis-reflektiiviseen oppimiseen. Sen sijaan Habermasilla (1971, 1972) on kolme oppimismuotoa: tekninen, praktinen ja emansipatorinen. Hänen emansipatorinen oppimis-muotonsa muistuttaa Freiren ongelman-asettelukasvatusta, mutta se ei ole aivan sama kuin innovatiivis-reflektiivinen oppiminen, jota tässä käsitellään. Sanaa innovatiivinen käytetään tässä mieluummin kuin sanaa emansipatorinen, koska viimeksimainittuun sanaan liittyvät mielleyhtymät ovat vallankumouksellisia. Vaikka innovaatio voi olla myös vallankumouksellista, niin sen ei tarvitse olla sitä. Siksi sanalla pyritään tässä vies- 
timään muutosta yleensä, eikä vain vallankumouksellista muutosta.

On tarpeen tutkia näitä oppimismuotoja niiden laajemmassa sosiaalisessa kontekstissa. Ne reflektiiviset oppimismuodot, jotka johtavat konformistisiin tuloksiin, eivät selvästikään vaikuta kovin paljoa yhteiskunnalliseen tilanteeseen, kun taas innovatiiviset oppimismuodot saattavat nimenomaan vaikuttaa siihen. On kuitenkin huomattava, että koska oppimista on tapahtunut, käyttäytymistulos ei aina ole yhdenmukainen oppimisen kanssa. Niinpä henkilö on voinut tehdä oppimisprosessin seurauksena innovatiivisia johtopäätöksiä, mutta hän on voinut myös päättää, ettei ole soveliasta toteuttaa niitä käytännön sosiaalisessa kontekstissa; tämä liittyy osittain Argyrisin analyysiin omaksutusta teoriasta ja teoriasta käytännössä. Mutta ehkäpä päätös olla toteuttamatta teoriaa käytännössä saattaa vastata myös omaksuttua teoriaa! Tämä yhteensopimattomuus kohoaa tärkeään asemaan tässä analyysissa. Miksi teoriat ovat yhteensopimattomia? Miksi ei niitä ideoita, jotka ovat syntyneet reflektiivisessa oppimisprosessissa, voitaisi ilmaista tai toteuttaa? Ehkä siksi, että henkilö ei halua loukata ystäväänsä tai työtoveriaan. Mutta syynä voi olla myös se, että sosiaalisen kontekstin sisäiset valta/statussuhteet eivät kannusta tällaiseen vapaaseen ilmaisuun.

Tässä vaiheessa on asetettava kolme kysymystä. Ensiksi, miksi reflektiivinen oppimisprosessi näyttää tuottavan konformistisia tuloksia? Toiseksi, miksi innovatiivisten tulosten pitäisi olla mahdollisia? Kolmanneksi, mitä ovat innovatiivisen oppimisen vaikutukset sosiaalisessa kontekstissa?

Ihmiset ovat aiemmin oppimisensa tulos, he heijastavat suuressa määrin omaa menneisyyttään. Mannheim $(1936,2)$ kirjoittaa:

Yksittäinen ihminen luo vain hyvin rajoitetussa mielessä itse sen puhe- ja ajattelutavan, jonka me liitämme häneen. Hän puhuu ryhmänsä kieltä; hän ajattelee ryhmänsä tavalla. Hän huomaa käytössään olevan vain tiettyjä sanoja ja niiden merkityksiä.

Ihmiset ovat siksi yhteiskunnallisia tuotteita, jotka käyttävät oman sosiaalis-kulttuuris-ajallisen ympäristönsä kieltä ja ajattelumalleja. Sen takia ihmiset tahtovat ajatella samalla tavalla ja päätyä samoihin johtopäätöksiin. Sen takia ihmisillä on taipumus päätyä yhdenmukaisiin ratkaisuihin.

Pitäisikö sitten innovatiivista ajattelua olla lainkaan? Saamme jälleen vastauksen Mannheimilta. Kirjoittaessaan älymystöstä (1936, 10) hän esittää, että koska älymystön jäsenten tausta oli hyvin vaihteleva, he toivat monet erilaiset maailmantulkinnat yhteen ja siksi in- novatiiviset ajatukset olivat mahdollisia. Pluralismi tekee uudistavat ajatukset mahdollisemmiksi, koska siinä sekä myönnetään vaihtoehtoisten näkökantojen olemassaolo että tunnettaan yleensä tarvetta tehdä jonkinlainen valinta näiden näkökantojen väliltä jne. Yksi nykyajan piirteitä on se, että meillä on käytettävissä vaihtelevia tulkintoja monista ilmiöistä, jos niitä vain sallitaan vapaasti esittää. Tästä syystä on mahdollista eritellä ja yhdistellä eri tulkintoja ja tavoitella näin uusi ajatuksia. Tämä ei ole vain älymystön tehtävä nyky-yhteiskunnassa, se on kaikkien ihmisten ulottuvilla oleva mahdollisuus - edellyttäen että tieto on heidän käytettävissään. Tämän takia tiedon tuotannon ja jakelun valvonnasta tulee nyky-yhteiskunnassa hyvin tärkeä.

Mitä yhteiskunnallisia vaikutuksia innovatiivis-reflektiivisen oppimisen harjoittamisella sitten on? Tämä on yhteydessä siihen yhteiskunnalliseen asemaan, joka oppijalla on yhteiskunnassa. Yhteiskunta jaetaan tässä analyysissa ylempään ja alempaan kerrostumaan karkea mutta hyödyllinen ja kekseliäs jako. Jos oppijat kuuluvat yhteiskunnan ylempiin kerrostumiin, heidän voi olla helpompaa esittää uusia ajatuksiaan ja he saattavat myös huomata, että heidät hyväksytään paljon helpommin, mikäli he eivät sodi eliitin asemaa vastaan. Sen sijaan yhteiskunnan alemmilla portailla olevista ihmisistä voi tuntua paljon hankalammalta löytää ilmaisuväyliä ajatuksilleen ja heidän voi olla vaikeampaa saada ne hyväksytyiksi. Jos ajatukset edistävät vallassaolijoiden asemaa, oppijista voi tuntua, että heidät hyväksytään ja että myös heidän ideansa hyväksytään. Mutta jos heidän ajatuksensa eivät sen sijaan valtaapitäviä miellytä, niin olivatpa he sitten yritysjohtoa tai poliittista eliittiä, niin tällöin he pitävät yhteiskunnallisia rakenteita tukahduttavina. Eliitti ei voi enää harjoittaa valtaansa peitellysti, jolloin he joutuvat käyttämään avointa valtaa vakiintuneiden asemiensa säilyttämiseksi. Freiren kaltaisten ajattelijoidén on näin pakko asettua vallankumouksellisten asemaan, koska heidän ideansa innovatiivis-reflektiivisestä oppimisesta kannustavat ihmisiä näkemään maailman eri valossa ja toimimaan sen muuttamiseksi. Tämä uhkaa eliitin vakiintuneita valta-asemia.

\section{Johtopäätökset}

Tässä artikkelissa on esitetty, että kaikki oppiminen lähtee kokemuksesta ja että on olemassa ainakin yhdeksän mahdollista tapaa oppia kokemuksen kautta. Nämä tavat voidaan luokitella kolmeen eri kerrostumaan: ei-oppiminen, ei-reflektiivinen oppiminen ja reflektiivinen oppiminen, Lisäksi todettiin, että jokaista reflektiivistä oppimistapaa kohden on kaksi 
tyyppiä, jotka ovat konformistinen ja innovatiivinen. Artikkelin tarkoitus on ollut osoittaa, että ei-oppimisessa, ei-reflektiivisessä ja konformistisessa reflektiivisessä oppimisessa oppimistulokset eivät synnytä muutostilannetta, eivätkä täten uhkaa millään tavalla eri organisaatioissa ja yhteiskunnassa hallitsevan eliitin asemaa. Siksi ihmiset voivat tuntea itsensä vapaiksi ja eliitti voi käyttää valtaansa peitellysti. Gramsci osoitti ja käsitteli ensimmäisenä tätä eliitin hegemonia-asemaa, josta ihmiset eivät ole yleensä tietoisia. Valtatilanne voi itsessään olla yksi syy ei-reflektiiviiseen oppimiseen ja se voi olla myös syy siihen, miksi näin ei saisi tapahtua! Kun taas innovatiivis-reflektiivistä oppimista tapahtuu, syntyy mahdollisuus muutokseen. Se että oppimistuloksen ilmaiseminen hyväksytään, saattaa jo sinällään olla ilmaus organisaation tai yhteiskunnan eliitin harjoittamasta vallasta. Lopuksi todetaan, että korkeammissa yhteiskunnallisissa asemissa olevien ihmisten on helpompi ilmaista innova- tiivis-reflektiivisen oppimisen tulokset.

Se, että oppiminen pyritään määrittelemään yhteiskunnallisesti ei-reflektiivisin oppimistermein, on osoitus yhteiskunnan rakenteiden voimasta. Se, että oppiminen on hallitsevasti konformistista luonteeltaan, on osoitus sosiaalisten rakenteiden voimasta. Se, että reflektiivinen oppiminen voi olla uudistavaa on kiistatonta. Mikään organisaatio tai yhteiskunta ei voisi kuitenkaan ylläpitää muutoksen mahdollisuutta koko ajan. Tätä ei myöskään mikään eliitti sietäisi, joten oppiminen pyritään yhteiskunnallisesti määrittelemään konformistisin termein. Jotkut sen sijaan pitävät innovatiivisreflektiivistä oppimista haittana. Näin siitä huolimatta, että sen tulokset osoittautuisivat kokonaisuudessaan hyödyllisiksi organisaation tai yhteiskunnan kannalta. Jotkut näkevät tällaisen oppimisen myös uhkaavana tai jopa kumouksellisena. Mitä kumouksellisempana se nähdään sitä useammin se määritellään vallankumoukselliseksi ajatteluksi. 


\section{AIKUISKASVATUS \\ The Finnish Journal of Adult Education \\ Vol. 9,1/89 \\ ISSN 0358-6197 \\ Summary}

Jarvis, Peter 1989. Three forms of learning in social context.

- The article deals with three different forms of learning in their social context. It is based on a project carried out in 1985 and 1986 to discover more about the way in which adults learn; some 200 persons in Britain and the United States taking part in adult studies were involved in the study. The study was based on Kolb's Learning Cycle model, but attempts were made to develop it further. It was observed that learning is always based on experience. Three basically different types of learning were classifield; i.e. non-learning, non-reflective learning and reflective learning. The author goes into to analysing in more detail the response models characteristic of these learning styles and their links with social context. 